\title{
Pengaruh Efektivitas Pelaksanaan Pengendalian Internal, Asimetri Informasi dan Ketaatan Aturan Akuntansi terhadap Akuntabilitas Organisasi dengan Kecenderungan Kecurangan Akuntansi Sebagai Variabel Intervening (Studi Empiris pada SKPD di Kabupaten Muara Jambi)
}

\author{
${ }^{1}$ Ahmad Soleh, ${ }^{2}$ Agus Maulana Hidayat, ${ }^{3}$ Asrini \\ ${ }^{1,3}$ Sekolah Tinggi Ilmu Ekonomi Muhammadiyah Jambi \\ ${ }^{2}$ Telkom University
}

\begin{abstract}
Based on the current conditions that the accountability of performance or financial responsibility for outcame on the use of budget in order to realize result oriented governance has not yet materialized, this shows the weakness of the Government's Internal Control System (SPIP) and Compliance with Accounting rules. The purpose of this study was to analyze the performance of the apparatus and public services in the Muaro Jambi district government so that the most appropriate strategies could be found in carrying out bureaucratic reforms in the government of Muaro Jambi Regency. This research was conducted in all SKPD in Muaro Jambi Regency. The data used in this study are secondary data collected from all agencies in the Jambi City Government, and the necessary literature and journal journals. The analytical model used is path analysis which consists of direct and indirect influences. The results showed that (1) The Effectiveness of Internal Control has a significant influence on Organizational Accountability, (2) Information Asymmetry has no significant effect on the Accountability of Regional Devices Organizations in Muaro Jambi Regency, (3) Compliance with Accounting Rules has no significant effect on the Accountability of District Regional Devices Muaro Jambi.
\end{abstract}

Keywords: Organization, Effectiveness, Accountability, Information

\section{PENDAHULUAN}

Perubahan paradigma manajemen pemerintahan yang semula berorientasi pada proses menjadi paradigma berorientasi hasil, telah mereformasi sistem pengelolaan keuangan di Indonesia. Reformasi pengelolaan keuangan negara di Indonesia yang diawali dengan ditetapkannya Undang-Undang No. 17 Tahun 2003 tentang Keuangan Negara telah membawa banyak perubahan mendasar dalam pengelolaan keuangan negara. Perubahan mendasar tersebut diantaranya adalah diperkenalkannya performance-based budgeting dalam penyusunan anggaran pemerintah. Akuntabilitas merupakan salah satu unsur pokok perwujudan good governance yang saat ini sedang diupayakan di Indonesia. Pemerintah diminta untuk melaporkan hasil dari program yang telah dilaksanakan sehingga masyarakat dapat menilai apakah pemerintah telah bekerja dengan baik secara ekonomis, efisien dan efektif (Adisetiawan dan Surono, 2016). Akuntabilitas diyakini mampu mengubah kondisi pemerintahan dari yang tidak memberikan pelayanan publik secara baik dan korup menuju suatu tatanan pemerintahan yang demokratis (Riantiarno dan Azlina, 2011). Berdasarkan data yang ada pada Kemen PAN-RB Tahun 2016, perkembangan capaian nilai rata-rata Akuntabilitas Kinerja Lembaga Pemerintah (Kementerian/Lembaga, Pemerintah Provinsi/Kabupaten/Kota seluruh Indonesia, berdasarkan hasil penilaian kinerja dan sistem akuntabilitas kinerja instansi pemerintah. Grafik 1 diatas menunjukkan bahwa tingkat Akuntabilitas Pemerintah Pusat secara umum mengalami peningkatan rata-rata 2,9\% dari Tahun 2010-2015, Akuntabilitas Pemerintah Daerah Provinsi di Indonesia mengalami peningkatan yang cukup signifikan rata-rata 3,5\%. Dan Akuntabilitas Pemerintah Daerah Kabupaten/Kota di Indonesia tidak mengalami peningkatan rata-rata 1,8\%. 
Grafik 1

Perkembangan Nilai Rata-Rata Akuntabilitas (dalam persentase)

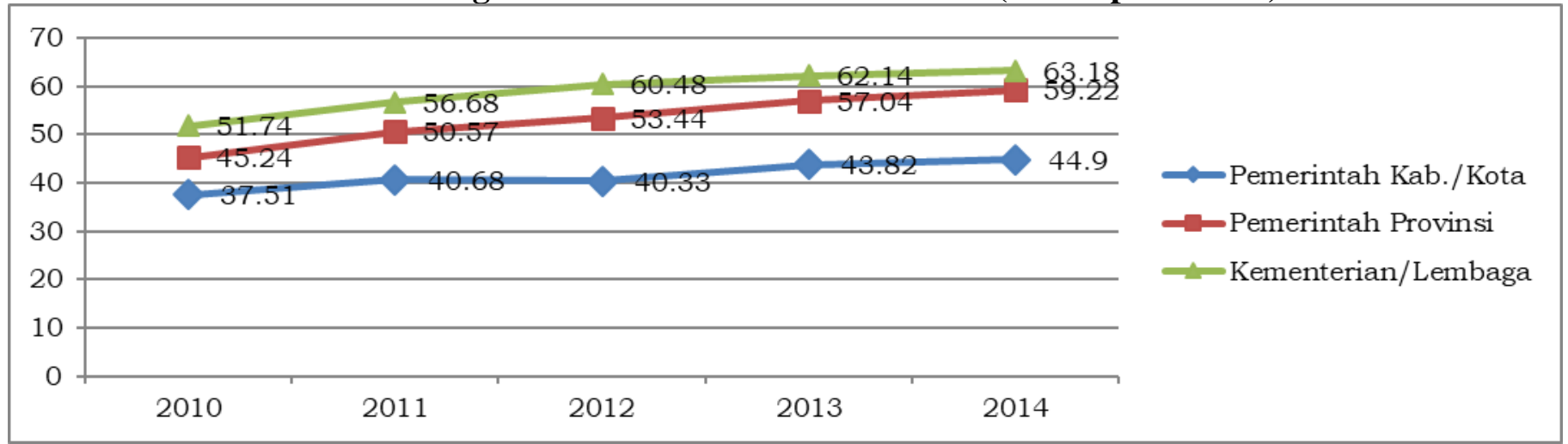

Sumber : Buklet KemenPAN-RB Tahun 2016

Sementara itu Perkembangan hasil penilaian Akuntabilitas Kinerja Pemerintah Kabupaten Muaro Jambi periode tahun 2012 - 2015 adalah :

\section{Grafik 2}

Perkembangan Nilai Rata-Rata Akuntabilitas Kinerja Pemerintah Kabupaten Muaro Jambi

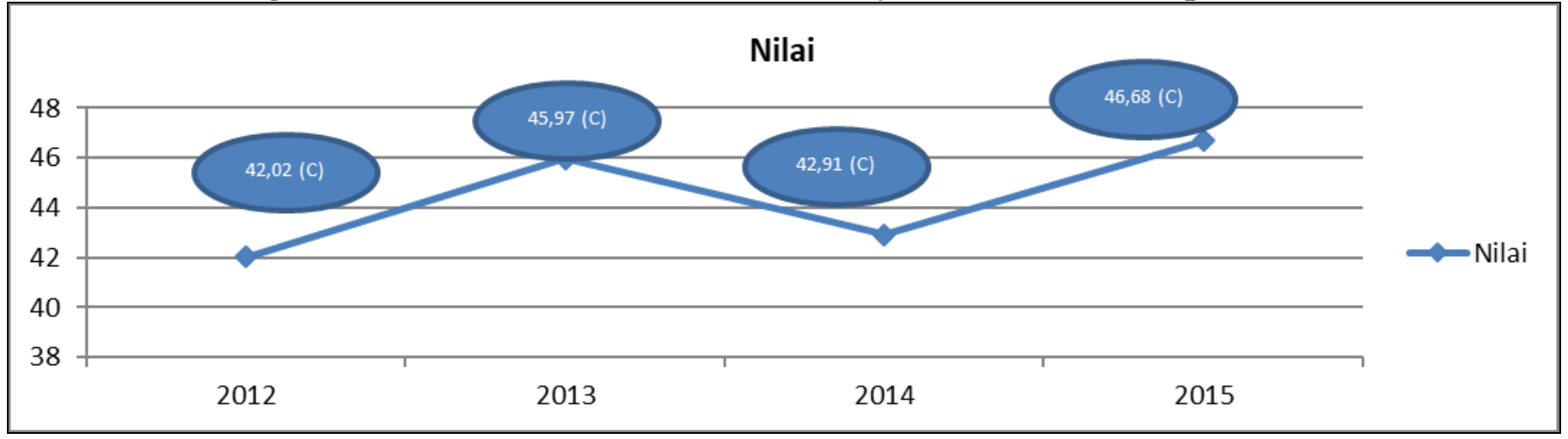

Sumber : Data Olahan Bagian ORTALA Setda Kab.Muaro Jambi.

Hasil penilaian Akuntabilitas Pemerintah Kabupaten Muaro Jambi pada Tahun 2012 - 2015 hanya peringkat C (kategori "kurang" skor 30-50). Hasil penilaian tersebut menggambarkan bahwa Akuntabilitas kinerja atau pertanggung jawaban keuangan atas hasil (outcame) terhadap penggunaan anggaran dalam rangka mewujudkan pemeritahanan yang berorientasi hasil (result oriented governance) belum terwujud. Hal ini menunjukkan masih lemahnya Sistem Pengendalian Internal Pemerintah (SPIP) dan Ketaatan aturan Akuntansi. Tujuan dari dilakukannya penelitian ini adalah (1) Untuk menganalisis kinerja aparatur dan pelayanan publik pada pemerintah Kabupaten Muaro Jambi dan, (2) Untuk menganalisis strategi yang paling tepat dalam melakukan revormasi birokrasi pada pemerintah Kabupaten Muaro Jambi.

\section{METODE PENELITIAN}

Pengumpulan data penelitian dilakukan dengan teknik angket/kuesioner yang merupakan daftar pertanyaan terstruktur dengan alternatif (option) jawaban yang telah tersedia sehingga responden tinggal memilih jawaban sesuai dengan aspirasi, persepsi, sikap, keadaan atau pendapat pribadinya dengan menggunakan pendekatan Cross sectional. Skala pengukuran dalam penelitian ini menggunakan skala ordinal, dengan mengkategorikan variabel kedalam kelompok, dan melakukan rangking terhadap ketegori, yang berbentuk skala likert yang berisi lima tingkat preferensi jawaban. Skala likert adalah skala yang digunakan untuk mengukur pendapat, sikap dan persepsi seseorang atau kelompok tentang kejadian atau

Pengaruh Efektivitas Pelaksanaan Pengendalian Internal, Asimetri Informasi dan Ketaatan Aturan Akuntansi terhadap Akuntabilitas Organisasi dengan Kecenderungan Kecurangan Akuntansi Sebagai Variabel Intervening (Studi Empiris pada SKPD di Kabupaten Muara Jambi) 
gejala sosial. Urutan pengukuran Likert tersebut mempunyai gradasi dari sangat positif sampai sangat negative, dengan kriteria: Sangat Setuju (SS) : Skor 5: Setuju (S); Skor 4: Netral (N); Skor 3: Tidak Setuju (TS) : Skor 2; Sangat Tidak Setuju (STS) : Skor 1. Alasan digunakan skala Likert 5 dengan pilihan "netral" adalah untuk mengindikasi item pernyataan dalam kuisioner yang tidak dimengerti dan tidak diketahui oleh responden. (Adisetiawan dan Surono, 2011)

\section{Analisis Data}

Tehnik analisis data dalam penelitian ini menggunakan analisis jalur yang terdiri dari pengaruh langsung dan tidak langsung. Untuk mendapatkan nilai pengaruh langsung dan tidak langsung digunakan analisis regresi dengan variabel intervening (variabel antara atau mediating) yang berfungsi memediasi hubungan antara variabel independent dan dependent. Hubungan dalam variabel dalam penelitian ini dapat dilihat pada gambar dibawah ini.

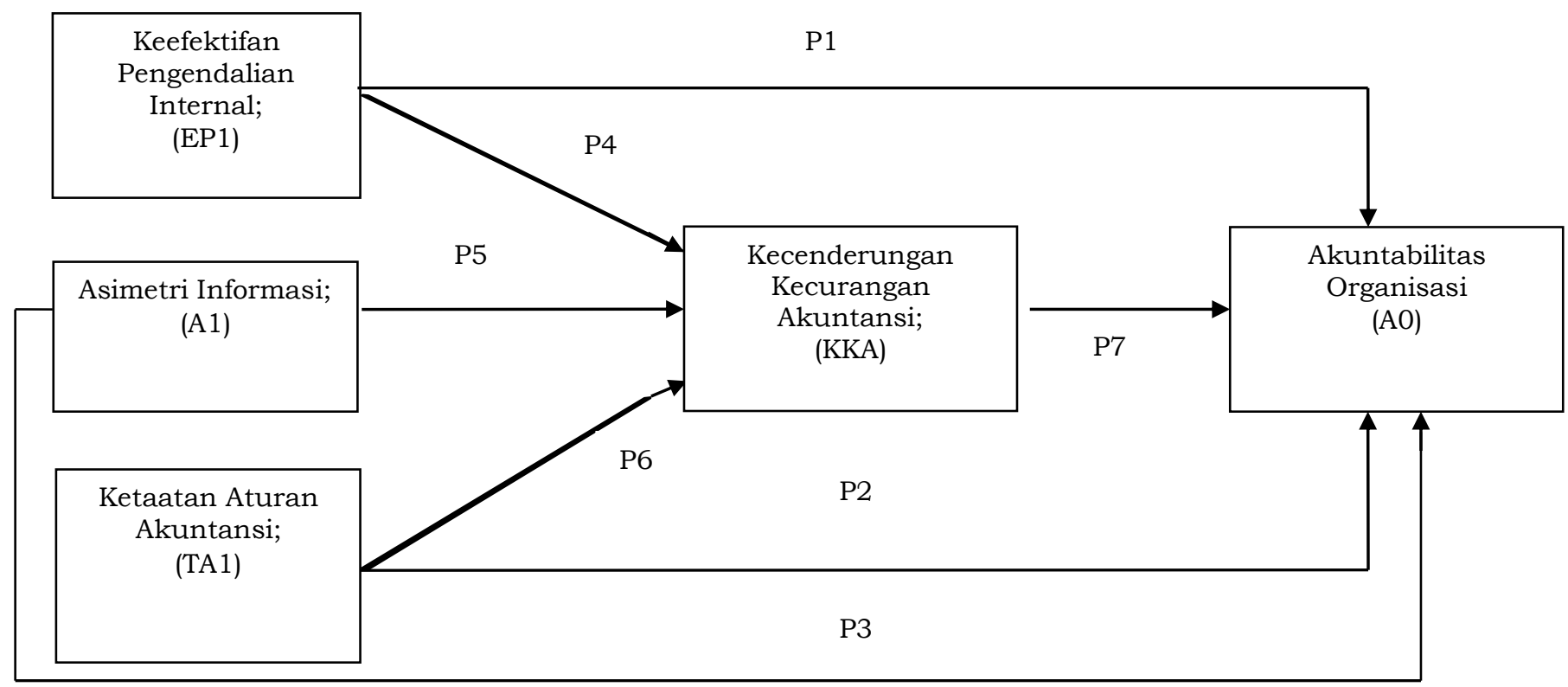

\section{Pengaruh Langsung}

Pengaruh langsung dalam penelitian ini ditunjukkan pada parameter P1, P2, P3 yang diperoleh dari hasil regresi antara keefektifan pengandalian internal dengan akuntabilitas organisasi, asimetri informasi dengan akuntabilitas organisasi dan ketaatan aturan akuntansi dengan akuntabilitas organisasi.

\section{Pengaruh tidak langsung}

Pengaruh tidak langsung dalam penelitian ini ada tiga yaitu ditunjukkan oleh parameter P4, P5, P6 melalui P7 yang merupakan nilai Standar coeficient (beta) yang diperoleh dari hasil regresi antara hubungan pengendalian internal terhadap akuntabilitas organaisasi melalui kecenderungan kecurangan akuntansi, asimetri informasi terhadap akuntabilitas organisasi melalui kecenderungan kecurangan akuntansi dan ketaatan aturan akuntasi terhadap akuntabilitas organisasi melalui kecenderungan kecurangan akuntansi.

\section{HASIL DAN PEMBAHASAN}

\section{Pengaruh variabel efektivitas pengendalian internal terhadap akuntabilitas organisasi.}

Hasil perhitungan analisis menunjukkan bahwa pada Organisasi Perangkat Daerah Kabupaten Muaro Jambi Efektivitas Pengendalian Internal memberikan pengaruh signifikan terhadap Akuntabilitas Organisasi. Hal ini disebabkan karena nilai $t$-Value atau C.R. sebesar $2.143 \geq 1,967$ atau nilai P sebesar 0,032 $\leq 0,05$. Artinya Keefektifan pengendalian internal berpengaruh signifikan terhadap Akuntabilitas Organisasi Perangkat Daerah Kabupaten Muaro Jambi, semakin meningkat pelaksanaan pengendalian internal maka 
akan semakin meningkatkan Akuntabilitas Organisasi Perangkat Daerah Kabupaten Muaro Jambi. Akuntabilitas Organisasi dibentuk dari lima indikator-indikator yang diurutkan berdasarkan kuatnya loading factors dari model penelitian yang terbentuk pada CFA Konstruk Endogenterhadap variabel laten Akuntabilitas Organisasi. Indikator diurutkan berdasarkan kuatnya loading factors (Squared multiple correlations) sebagai berikut : (1) akurasi penggunaan dana (AO5 - 0,499), dan (AO4 - 0,434), (2) informasi dan komunikasi (AO7 - 0,317), (3) perencanaan (AO3 - 0,282), dan (4) penyajian(AO2 - 0,273). Secara keseluruhan indikator - indikator tersebut cukup mampu membentuk konstruk dengan baik. Konstribusi terbesar dari Indikator ini adalah akurasi penggunaan dana yang terdiri dari pelaporan yang akurat dan jelas serta kesesuaian dengan perencanaan jangka menengah. Hasil penelitian ini menunjukkan bahwa Organisasi Perangkat Daerah di Kabupaten Muaro Jambi secara keseluruhan pelaporannya telah menggunakan aplikasi SIAKAD sehingga pelaporan penggunaan dana telah disajikan secara komprehensif. Hal ini disebabkan input data yang dilaksanakan pada saat rekonsiliasi penerimaan dan pengeluaran di KASDA langsung menjadi input dalam pembuatan laporan secara lengkap setiap bulannya.

Indikator terbesar kedua yang memberikan konstribusi membentuk akuntabilitas organisasi adalah informasi dan komunikasi dalam hal penyajian laporan keuangan secara informatif dengan sumber-sumber dan penggunaan dana yang jelas. Indikator ini dapat diterapkan dikarenakan format laporan yang seluruhnya dapat menggambarkan secara jelas sumber dan penggunaan dana program dan kegiatan setiap Organisasi Perangkat Daerah. Indikator ketiga yang dapat membentuk akuntabilitas organisasi adalah perencanaan meliputi keakuratan sumber-sumber penggunaan dana yang disesuaikan dengan kebutuhan dan target yang ditetapkan. Kecenderungan fenomena yang terjadi adalah target yang ditetapkan tidak terlaksana atau tidak tercapai hal ini dikarenakan adanya defisit anggaran sehingga program atau kegiatan dihapus/dihilangkan pada APBD Perubahan hal ini terlah sejak Tahun Anggaran 2014 sampai dengan Tahun Anggaran 2016 yang lalu. Kontribusi terakhir dalam membentuk akuntabilitas organisasi adalah indikator penyajian meliputi prosedur penyajian, sumber-sumber dan penggunaan dana. Temuan penelitian ini menunjukkan bahwa apabila pengendalian internal di Organisasi Perangkat Daerah Kabupaten Muaro Jambi berjalan secara efektif termasuk diantaranya pencatatan transaksi dengan bukti pendukung yang diotorisasi, sistem akuntansi yang baik, pemantauan dan evaluasi berkelanjutan, termasuk pengawasan fisik serta penerapan wewenang dan tanggung jawab maka akan meningkatkan Akuntabilitas Organisasi.

\section{Pengaruh variabel Asimetri informasi terhadap akuntabilitas organisasi.}

Hasil penelitian ini menunjukkan bahwa asimetri informasi berpengaruh tidak signifikan terhaadap Akuntabilitas Organisasi Perangkat Daerah Kabupaten Muaro Jambi. Dimana nilai $t$-Value atau C.R. sebesar $0,506 \leq 1,967$ atau nilai $P$ sebesar $0,613 \geq 0,05$. Artinya terjadi asimetri informasi pada Organisasi Perangkat Daerah di Kabupaten Muaro Jambi sehingga informasi belum sepenuhnya transparan dan dapat diakses dengan mudah oleh pengguna atau pihak yang membutuhkan informasi. Kualitas informasi belum dapat diandalkan hal ini disebabkan data dalam laporan keuangan belum merupakan gambaran dari data yang sebenarnya dari setiap transaksi dalam organisasi. Hal itu dibuktikan dengan pengaruh yang tidak signifikan dari asimetri informasi terhadap Akuntabilitas Organisasi Perangakat Daerah di Kabupaten Muaro Jambi. Akuntabilitas Organisasi Perangkat Daerah Kabupaten Muaro Jambi yang dalam hal ini adalah akuntabilitas keuangan hanya dapat terwujud apabila mampu menerapkan prinsip dasarnya yaitu harus jujur, objektif, transparan dan inovatif yang bertolak belakang dengan Asimetri informasi yang dibangun dari azas ketidak jujuran, tidak objektif, tidak transparan dan mengabaikan inovasi.

Alasan-alasan mengapa temuan empirik dari penelitian ini tidak mendukung hipotesis penelitian adalah : (1) tidak adanya transparansi pada Organisasi Perangkat Daerah Kabupaten Muaro Jambi; (2) akses informasi yang sulit didapat dan data yang disajikan tidak up to date; dan (3) Tidak adanya komitmen pimpinan dalam mengaktualisasikan konsep keterbukaan informasi publik. (adisetiawan, 2012)

\section{Penguruh variabel ketaatan aturan akuntansi terhadap akuntabilitas organisasi.}

Hasil analisis data menunjukkan bahwa ketaatan aturan akuntansi memberikan pengaruh tidak signifikan terhadap Akuntabilitas Organisasi Perangkat Daerah Kabupaten Muaro Jambi.Hal ini diketahui

Pengaruh Efektivitas Pelaksanaan Pengendalian Internal, Asimetri Informasi dan Ketaatan Aturan Akuntansi terhadap Akuntabilitas Organisasi dengan Kecenderungan Kecurangan Akuntansi Sebagai Variabel Intervening (Studi Empiris pada SKPD di Kabupaten Muara Jambi) 
dari nilai $t$-Value atau C.R. sebesar $1.097 \leq 1,967$ atau nilai $\mathrm{P}$ sebesar $0,273 \geq 0,05$. Artinya ketaatan aturan akuntansi belum optimal dalam upaya peningkatan Akuntabilitas Organisasi Perangkat Daerah Kabupaten Muaro Jambi, Hal itu dibuktikan dengan pengaruh yang tidak signifikan dari ketaatan aturan akuntansi terhadap Akuntabilitas Organisasi Perangakat Daerah di Kabupaten Muaro Jambi. Ketaatan terhadap aturan akuntansi merupakan implementasi dari kepatuhan terhadap peraturan perundang-undangan yang berlaku. Hasil penelitian ini telah membuktikan data awal yang dijelaskan pada latar belakang penelitian yang bersumber dari surat BPK Perwakilan Provinsi Jambi Nomor : 158/S/XVIII.JMB/5/2015 tanggal 22 Mei 2015 tentang Hasil Pemeriksaan tentang LKPD Kabupaten Muaro Jambi Tahun 2014 yang menunjukkan bahwa temuan hasil pemeriksaan tersebut terbanyak pada point kepatuhan terhadap peraturan perundangundangan (5 point) artinya masih lemahnya penerapan aturan khususnya aturan akuntansi pada Organisasi Perangkat Daerah Kabupaten Muaro Jambi.

\section{Pengaruh efektivitas pengendalian internal, asimetri informasi dan ketaatan aturan akuntansi terhadap akuntabilitas organisasi melalui kecenderungan kecurangan akuntansi pada SKPD di Lingkungan Pemerintah Kabupaten Muara Jambi.}

Hasil analisis data menunjukkan bahwa pengaruh efektivitas pengendalian internal, asimetri informasi dan ketaatan aturan akuntansi terhadap akuntabilitas organisasi melalui kecenderungan kecurangan akuntansi adalah sebagai berikut :

Tabel 1

Standardized Indirect Effects (Group number 1 - Default model)

\begin{tabular}{llllll}
\hline & TA & EP & AI & KKA & AO \\
\hline KKA &, 000 &, 000 &, 000 &, 000 &, 000 \\
AO &,- 006 &, 028 &,- 005 &, 000 &, 000 \\
\hline
\end{tabular}

Sumber: data olahan

Tabel 1 diatas menunjukkan pengaruh tidak langsung Efektivitas Pengendalian Internal terhadap Akuntabilitas organisasi sebesar 0,028. Pengaruh tidak langsung melalui Kecenderungan kecurangan akuntansi terhadap Akuntabilitas Organisasi sebesar 0,028 dan pengaruh tidak langsung Kecenderungan kecurangan akuntansi terhadap Akuntabilitas Organisasi sebesar $(-0,006)$ serta pengaruh tidak langsung Asimetri Informasi Kecenderungan kecurangan akuntansi (sebesar -0,006). Hasil penelitian ini menunjukkan bahwa tidak semua variabel terukur (observed variabel) yang signifikan. Hanya variabel terukur Efektivitas Pengendalian Internal yang signifikan terhadap variabel endogen Kecenderungan Kecurangan Akuntansi maupun Akuntabilitas Organisasi. Pada variabel terukur Ketaatan aturan akuntasi indikator yang tidak signifikan membentuk konstruk variabel laten antara lain integritas yang tercermin dari kejujuran dalam hal mengungkap seluruh kejadian atau transaksi dalam organisasi, obyektivitas dalam penerapan prinsip sesuai dengan fakta dan aturan yang ada dan mampu membebaskan diri dari pengaruh kepentingan dari pihak lain yang bertentangan dengan aturan akuntansi yang berlaku, serta konsisten dalam menerapkan aturan akuntansi.

Hal ini dibuktikan dari jawaban responden (40\%) yang menerima atau setuju pernyataan dalam menyusun laporan keuangan, sangatlah sulit bagi penanggung jawab penyusunan laporan keuangan di organisasi ini untuk mengungkapkan seluruh kejadian dan transaksi keuangan yang ada di organisasi (TA2). Dan jawaban responden $(40,7 \%)$ yang tidak menerima atau tidak setuju pernyataan dalam menyusun laporan keuangan, penanggungjawab penyusunan laporan keuangan di organisasi ini harus berusaha membebaskan diri dari berbagai pengaruh kepentingan tertentu dari pihak lain yang bertentangan dengan ketentuan yang berlaku (TA3). Selanjutnya jawaban responden (38\%) yang menerima atau setuju dengan pernyataan bila mengalami kesulitan dalam melaksanakan tugas, penanggungjawab penyusunan laporan keuangan di organisasi ini tidak harus mentaati ketentuan organisasi secara konsisten (TA6).

Pada variabel terukur Asimetri Informasi indikator yang tidak signifikan membentuk konstruk variabel laten adalah unsur transparansi informasi dan akses informasi. Hal ini dibuktikan dari jawaban

Pengaruh Efektivitas Pelaksanaan Pengendalian Internal, Asimetri Informasi dan Ketaatan Aturan Akuntansi terhadap Akuntabilitas Organisasi dengan Kecenderungan Kecurangan Akuntansi Sebagai Variabel Intervening (Studi Empiris pada SKPD di Kabupaten Muara Jambi) 
responden $(61,40 \%)$ yang tidak menerima atau tidak setuju pernyataan atas pekerjaan di bidang akuntansi, pihak luar baik langsung atau tidak langsung juga mengetahui seluruh informasi yang berkaitan dengan transaksi SKPD yang mempunyai dampak keuangan (AI1). Dan jawaban responden (66\%) yang tidak menerima atau tidak setuju pernyataan pihak luar, baik langsung atau tidak langsung selalu mengetahui dan memahami isi dan angka laporan keuangan yang selesai dikerjakan (AI3). Selanjutnya jawaban responden $(70,60 \%)$ yang tidak menerima atau tidak setuju dengan pernyataan pihak luar, baik langsung atau tidak langsung juga mengetahui faktor eksternal yang mempengaruhi kegiatan pembuatan laporan keuangan(AI5) dan responden $(63,40 \%)$ pihak luar, baik langsung atau tidak langsung juga mengetahui faktor internal yang mempengaruhi kegiatan pembuatan laporan keuangan(AI6).

\section{Strategi meningkatkan Akuntabilitas Laporan Keuangan di Lingkungan Pemerintah Kabupaten Muara Jambi}

Membangun budaya akuntabilitas mengingat semakin menurunnya nilai nilai kerja sehingga enggan melakukan pekerjaannya, menolak tanggung jawab dan bergantung pada orang lain untuk memecahkan masalah. Dalam menciptakan akuntabilitas dapat dimulai dengan leadership. Berikut ada delapan hal yang bisa dilakukan pemimpin dalam rangka menciptakan budaya akuntabilitas dengan memberikan contoh positif terhadap bawahaannya; menentukan target dan capaian, berkomitmen, memperkerjakan pegawai yang memiliki akuntabilitas, konsekuensi dan dukungan dan mempertahankan akuntabilitas.

1. Meningkatkan kemampuan atau kinerja para pegawai sehingga lebih tepat antara target dan rencana yang akan dilaksanakan sehingga sistem laporan keuangan dapat berjalan dengan tepat.

2. Melakukan sistem tranparasi laporan keuangan kepada masyarakat sehingga secara tidak langsung masyarakat akan ikut mengawasi pelaksanaan dan pelaporan kegiatan yang dilakukan.

3. Penguatan pemantauan dan monitoring serta pemanfaatan teknologi informasi diantarannya penggunaan sidik jari atau scan photo untuk verifikasi kehadiran pegawai di setiap oraganisasi perangkat daerah Kabupaten Muaro Jambi.

4. Memberikan Akses Informasi yang transparan dan up to date pada Website resmi Pemerintah Daerah.

5. Penetapan peraturan Bupati Muaro Jambi tentang Sistem Pengendalian Internal Pemerintah Kabupaten Muaro Jambi.

6. Penerapan reward dan punisment serta jenjang karier yang jelas dalam upaya mendorong inovasi dan kreatifitas Pegawai Negeri Sipil di lingkungan Pemerintah Kabupaten Muaro Jambi.

7. Pengembangan penelitian selanjutnya agar menambahkan variabel kesesuaian kompensasi, teknologi informasi, budaya organisasi, perilaku tidak etis dan perilaku negatif pengawasan.

8. Selain itu juga dapat di lakukan dengan cara pembinaan, sosialisasi, bimbingan teknis, audit, reviu dan evaluasi program dan kegiatan serta pertanggung jawabannya.

\section{SIMPULAN}

Dari hasil penelitian yang telah dilakukan maka di peroleh beberapa kesimpulan sebagai berikut :

1. Efektivitas Pengendalian Internal memberikan pengaruh signifikan terhadap Akuntabilitas Organisasi. Hal ini disebabkan karena nilai $t$-Value atau C.R. sebesar 2.143 $\geq 1,967$ atau nilai P sebesar $0,032 \leq 0,05$.

2. Asimetri Informasi berpengaruh tidak signifikan terhaadap Akuntabilitas Organisasi Perangkat Daerah Kabupaten Muaro Jambi. Dimana nilai $t$-Value atau C.R. sebesar 0,506 $\leq 1,967$ atau nilai $P$ sebesar 0,613 $\geq 0,05$.

3. Ketaatan Aturan Akuntansi memberikan pengaruh tidak signifikan terhadap Akuntabilitas Organisasi

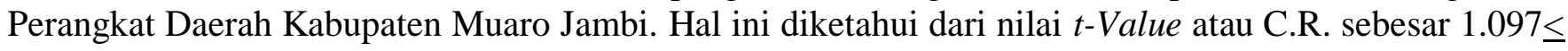
1,967 atau nilai $P$ sebesar $0,273 \geq 0,05$.

4. Hasil analisis data menunjukkan bahwa pengaruh efektivitas pengendalian internal, asimetri informasi dan ketaatan aturan akuntansi terhadap akuntabilitas organisasi melalui kecenderungan kecurangan akuntansi adalah sebagai berikut : 
a. Dari Tabel diatas menunjukkan pengaruh tidak langsung Efektivitas Pengendalian Internal terhadap Akuntabilitas organisasi sebesar 0,028. Pengaruh tidak langsung melalui Kecenderungan kecurangan akuntansi terhadap Akuntabilitas Organisasi sebesar 0,028 dan pengaruh tidak langsung Kecenderungan kecurangan akuntansi terhadap Akuntabilitas Organisasi sebesar $(-0,006)$ serta pengaruh tidak langsung Asimetri Informasi Kecenderungan kecurangan akuntansi (sebesar -0,006).

b. Hasil penelitian ini menunjukkan bahwa tidak semua variabel terukur (observed variabel) yang signifikan. Hanya variabel terukur Efektivitas Pengendalian Internal yang signifikan terhadap variabel endogen Kecenderungan Kecurangan Akuntansi maupun Akuntabilitas Organisasi. Pada variabel terukur Ketaatan aturan akuntasi indikator yang tidak signifikan membentuk konstruk variabel laten antara lain integritas yang tercermin dari kejujuran dalam hal mengungkap seluruh kejadian atau transaksi dalam organisasi, obyektivitas dalam penerapan prinsip sesuai dengan fakta dan aturan yang ada dan mampu membebaskan diri dari pengaruh kepentingan dari pihak lain yang bertentangan dengan aturan akuntansi yang berlaku, serta konsisten dalam menerapkan aturan akuntansi.

\section{DAFTAR PUSTAKA}

Adisetiawan, R., 2012. Analisis Pengaruh Kinerja Keuangan dalam Memprediksi Pertumbuhan Laba, Jurnal Aplikasi Manajemen, 10(3), 669-681

Adisetiawan, R., and Surono, Yunan, 2016. Earnings Management and Accounting Information Value: Impact and Relavance, Business, Management and Economics Research, 2(10), 170-179

Adisetiawan, R., dan Surono, Yunan., 2011, Analisa Pengaruh Variabel-variabel Fundamental Terhadap Return Saham LQ45, Jurnal Ilmiah Universitas Batanghari Jambi, 11(2), 21-31

Fahmi, Irham. 2013, Pengantar Manajemen Keuangan, Teori Soal dan Jawab, Bandung: Alfabeta

Hikam Lazuardy, 2016, Analisis Pengukuran Kinerja Keuangan Dengan Model Altman Z-Score dan Tobin's Q. Studi Kasus Pada Perusahaan Sektor Makanan Dan Minuman Di BEI Periode 2010-2014.

Riantiarno, R., dan Azlina, N, 2011, Faktor-faktor yang Mempengaruhi Akuntabilitas Kinerja Instansi Pemerintah (Studi pada Satuan Kerja Perangkat Daerah Kabupaten Rokan Hulu). Jurnal Pekbis, Vol. 3, No. 3. 